\title{
First record of the Sclerogibbidae (Hymenoptera) from the Galapagos Islands, Ecuador
}

Author(s): Fernando Fernández, Carlos E. Sarmiento and Henri W. Herrera

Source: Pan-Pacific Entomologist, 94(1):27-31.

Published By: Pacific Coast Entomological Society

https://doi.org/10.3956/2018-94.1.27

URL: http://www.bioone.org/doi/full/10.3956/2018-94.1.27

BioOne (www.bioone.org) is a nonprofit, online aggregation of core research in the biological, ecological, and environmental sciences. BioOne provides a sustainable online platform for over 170 journals and books published by nonprofit societies, associations, museums, institutions, and presses.

Your use of this PDF, the BioOne Web site, and all posted and associated content indicates your acceptance of BioOne's Terms of Use, available at www.bioone.org/page/ terms of use.

Usage of BioOne content is strictly limited to personal, educational, and non-commercial use. Commercial inquiries or rights and permissions requests should be directed to the individual publisher as copyright holder. 


\section{Scientific Note}

\section{First record of the Sclerogibbidae (Hymenoptera) from the Galapagos Islands, Ecuador}

The Galapagos Islands are of great importance due to their role at the dawn and consolidation of the Darwinian model of evolution (Sulloway 1982); their geologically recent origin and oceanic location make them a natural laboratory for the study of many evolutionary and ecological processes (Schluter 1986, Grant \& Grant 2009). As a consequence, several groups of organisms, such as vertebrates, have been extensively studied (De Roy 2009, Steadman 2009); however, basic questions such as the richness of the islands require more study, and surprises continuously appear, even from the more obvious groups such as vertebrates themselves (Gentile \& Snell 2009).

Arthropoda are a group for which the inventory of the islands has been unevenly developed and still requires a large effort despite the multiple expeditions conducted. According to Linsley \& Usinger (1966), at the time the best compendium of entomological studies, since the pioneering visit by Charles Darwin in 1835 until 1966, around eight individual and 21 group expeditions had occurred resulting in a list of 618 species: 192 Coleoptera, 97 Lepidoptera, and 31 Hymenoptera. Several decades later, Peck (2006) reported 486 coleopteran species, Roque-Álbelo \& Landry (2016) listed 311 lepidopterous species, and Heraty \& Herrera (2017) compiled a total of 71 hymenopterans. Interestingly, large hymenopteran groups such as Braconidae, Pteromalidae and Encyrtidae are either not listed or are mentioned in publications with fewer than five species (Heraty \& Herrera 2017).

Despite the fact that the biota of the islands may have come from earlier dispersals such as in those reported for cyrtacanthacridine locusts (Lovejoy et al. 2006), and that these newcomers served for subsequent speciation and diversification events (Parent et al. 2008, Peck 1996), current human travel may be imposing a large-scale immigration process (Bataille et al. 2009, Tullis 2006), some of which is affecting the local fauna (Kleindorfer \& Dudaniec 2016). Herrera et al. (2014) listed 51 species of ants, of which 36 are introduced. Within these there are well-known examples of high-impact species such as Solenopsis geminata (Fabricius, 1804), Wasmannia auropunctata (Roger, 1863) and Pheidole megacephala (Fabricius, 1793) (Lubin 1984, Williams \& Whelan 1991, Herrera \& Causton 2008, Herrera et al. 2013). Another well-known case is the bird-parasite muscid fly Philornis downsi Dodge \& Aitken, 1968, which is affecting populations of Darwin's finches (Fessl \& Tebbich 2002, Bulgarella et al. 2015).

Hence, a complete inventory of species with precise information on their geographic relationships is of vital importance for conservation programs. After a revision of the entomological collection of the Charles Darwin Foundation (CDF) Station, we noticed the presence of the uncommon wasp family Sclerogibbidae (Hymenoptera). Herein, we provide the pertinent record for this group in the islands and discuss its origins.

The insect collection of the Charles Darwin Research Station (ICCDRS) at Puerto Ayora (Santa Cruz Island) was sorted and identified with the help of updated keys (Fernández \& Sharkey 2006). Specimens of Sclerogibbidae were identified using Olmi $(2005,2006)$ and later confirmed by Massimo Olmi. 
Caenosclerogibba sp. (Figure 1).

Specimens Examined: 2 females; label 1: "Ecuador, Galápagos: Sta Cruz-Pto. Ayora, La Cascada, -0.7342065; -90.3126545, 16-20.I.2006 P. Lincango \& E. Lomas Pitfall 2.”; label 2: “/12 sp21.”. ICCDRS41722, ICCDRS42723.

These two females constitute the first record of the genus and family for the Galapagos Islands. The family is distributed worldwide but is uncommonly collected. Caenosclerogibba Yasumatsu, 1958 is the most widespread genus in the family and has been reported from Africa, several regions of Asia, and the New World; recently, new records extended its occurrence southward into Southeast Asia (Lucañas \& Olmi 2017). Only two records have been published from the New World, one from Mexico and another from continental Ecuador (Olmi 2005). The identification to species of the specimens from the Galapagos was not possible because it requires dissection of the labial palps (M. Olmi pers. comm.), and the specimens are dried and mounted on insect pins.

Sclerogibbidae are parasitoids of webspinners (Embiodea), such as Caenosclerogibba longiceps (Richards, 1958) reared from Oligotomidae and Embiidae (Lucañas \& Olmi 2017). Two species of Embiodea have been reported from the Galapagos Islands, Chelicerca galapagensis Ross, 1966 and Oligotoma saundersii (Westwood, 1837). The former is endemic to the islands and distributed in Pinzon, San Cristobal, Santa Cruz, and Wolf Islands. This species is found in both arid and humid forests of the Galapagos feeding on detritus or lichens, and is related to the coastal species of Embiodea found in arid areas of Ecuador and Peru (Peck 2001). Oligotoma saundersii is a widespread species dispersed by commerce throughout the tropics; in the Galapagos this embiodean is recorded from Santa Cruz and San Cristobal Islands; in Santa Cruz it was reported around the area of Puerto Ayora (Peck 2001).
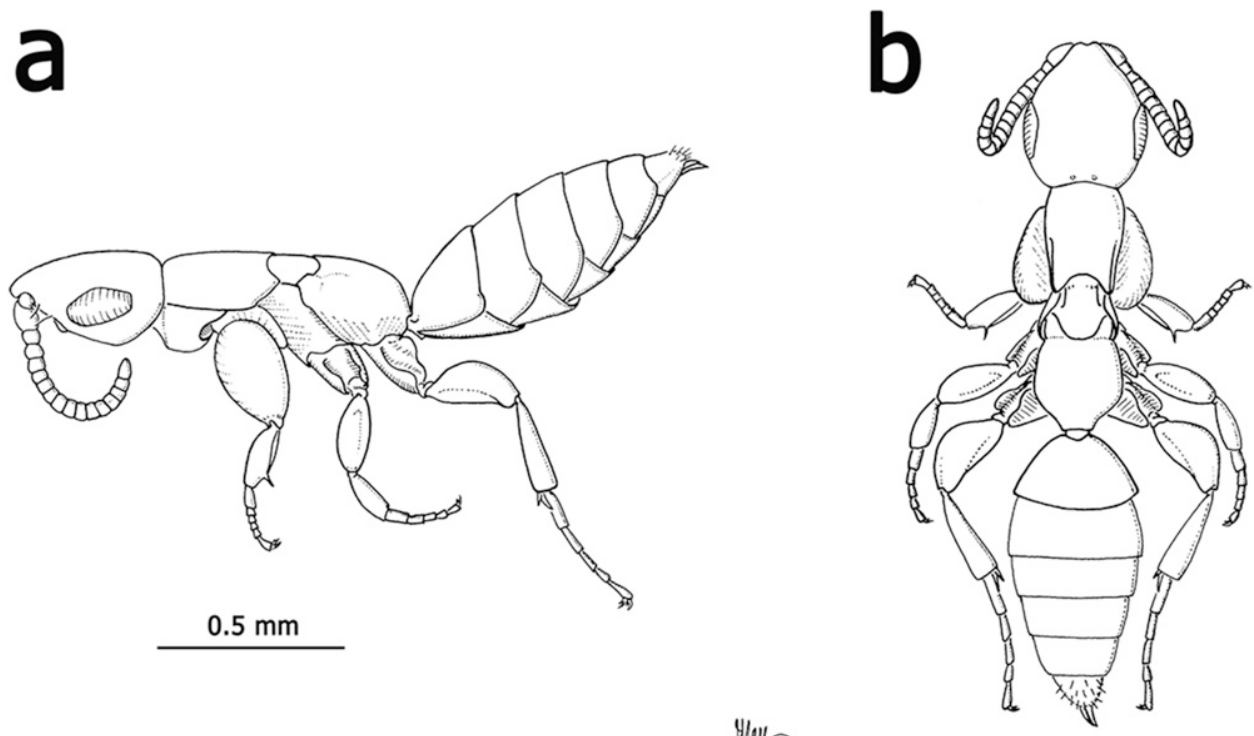

Whe

Figure 1. Habitus of the female of Sclerogibbidae found on Santa Cruz, Galapagos Islands. A. lateral view, B. dorsal view. 
An extensive screening of the CDF collection conducted by the authors did not reveal additional Sclerogibbidae specimens. Thus, as has occurred with other insect species (Gonzalez et al. 2010), this report of the family on the island may be the result of either the rareness of the group and the lack of extensive sampling, or it may also be an accidental introduction through the frequent importation of wood for construction from the mainland. Embiodea often build their silken galleries in tree bark or rotten wood (Szumik 2012), and thus wood loads with webspinner colonies may serve as transportation vessels for Sclerogibbidae. In this regard, it is worth noting that the sclerogibbid specimens were collected in Puerto Ayora, the largest and most active port of the islands with heavy touristic activity. Furthermore, the recent report of $C$. longiceps in the Philippines has been interpreted as a consequence of the introduction of its hosts $O$. saundersii and $O$. humbertiana (Saussure, 1896) to the island through ancient Spanish trade routes (Lucañas \& Olmi 2017).

A more intensive and focused sampling of insects of the Galapagos Islands may help to provide fresh material of Sclerogibbidae and resolve the species identity of the Caenosclerogibba reported here. In doing so, the origin of this taxon might be determined, and thus we may obtain a better understanding of the ecological implications of the presence of the family in the islands.

Acknowledgments. The authors are grateful to the Charles Darwin Foundation for the invitation to study the Terrestrial Invertebrates Collection at Puerto Ayora. We also thank Dr. Massimo Olmi for his advice, Bradley Sinclair, Michael Engel and one anonymous reviewer for comments on the manuscript, and the Galapagos National Park Directorate for providing export permits for samples. This work was supported thanks to the Vice-Rectorate for Research of ESPOCH, the Research Institute of ESPOCH and the Universidad Nacional de Colombia. Paulina Pozo (ESPOCH), kindly assisted us with logistics. This publication is contribution number 2192 of the Charles Darwin Foundation for the Galápagos Islands and the number 0001 under cooperative agreement ESPOCH-FCD/2017-2022.

Fernando Fernández (corresponding author), Instituto de Ciencias Naturales, Universidad Nacional de Colombia, Bogotá D.C., Colombia, e-mail:ffernandezca@unal. edu.co; Carlos E. Sarmiento, Instituto de Ciencias Naturales, Universidad Nacional de Colombia, Bogotá D.C., Colombia, e-mail: cesarmientom@unal.edu.co; and Henri W. Herrera, Escuela Superior Politécnica de Chimborazo (ESPOCH), Facultad de Recursos Naturales Departamento de Entomología, (593) 032998220 (ext. 414), Panamericana Sur km. 1.5, Riobamba-Ecuador, e-mail: henri.herrera@espoch.edu.ec.

\section{Literature Cited}

Bataille, A., A. Cunningham, V. Cedeño, M. Cruz, G. Eastwood, D. M. Fonseca, C. E. Causton, R. Azuero, L. Loayza, J. D. Cruz Martinez \& S. J. Goodman. 2009. Evidence for regular ongoing introductions of mosquito disease vectors into the Galápagos Islands. Proceedings of the Royal Society Series B, Biological Sciences 276(1674):3769-3775.

Bulgarella M., M. A. Quiroga, G. A. Brito Vera, J. S. Dregni, F. Cunninghame, D. A. Mosquera Muñoz, L. D. Monje, C. E. Causton \& G. E. Heimpel. 2015. Philornis downsi (Diptera: Muscidae), an avian nest parasite invasive to the Galápagos Islands, in mainland Ecuador. Annals of the Entomological Society of America 108(3):242-250. 
De Roy, T. 2009. Galápagos, Cincuenta Años de Ciencia y Conservación. Parque Nacional Galápagos. Imprenta Aguilera, Quito, 237 pp.

Fernández, F. \& M. J. Sharkey. 2006. Introducción a los Hymenoptera de la región neotropical. Sociedad Colombiana de Entomología-Universidad Nacional de Colombia, Bogotá, 894 pp.

Fessl, B. \& S. Tebbich. 2002. Philornis downsi-a recently discovered parasite on the Galápagos archipelago - a threat for Darwin's finches? Ibis 144:445-451.

Gentile, G. \& H. L. Snell. 2009. Conolophus marthae sp. nov. (Squamata, Iguanidae), a new species of land iguana from the Galápagos Archipelago. Zootaxa 2201:1-10.

González, V. H., J. B. Koch \& T. Griswold. 2010. Anthidium vigintiduopunctatum Friese (Hymenoptera: Megachilidae): the elusive "dwarf bee" of the Galapagos Archipelago? Biological Invasions 12(8):2381-2383.

Grant, B. R. \& P. R. Grant. 2009. Los Pinzones de Darwin: estudiando la evolución en plena acción, pp. 122-129. In: T. De Roy (Ed). Galápagos, Cincuenta Años de Ciencia y Conservación. Parque Nacional Galápagos, Imprenta Aguilera, Quito, 237 pp.

Herrera, H. W. \& C. E. Causton. 2008. Distribution of fire ants Solenopsis geminata and Wasmannia auropunctata (Hymenoptera: Formicidae) in the Galápagos Islands. Galápagos Research 65:11-14.

Herrera, H. W., C. R. Sevilla \& W. Dekoninck. 2013. Pheidole megacephala (Fabricius, 1793) (Hymenoptera: Formicidae): a new invasive ant in the Galapagos Islands. The Pan-Pacific Entomologist 89(4):234-243.

Herrera, H. W., J. T. Longino \& W. Dekoninck. 2014. New records of nine ant species (Hymenoptera: Formicidae) for the Galapagos Islands. The Pan-Pacific Entomologist 90(2):72-81.

Heraty, J. M. \& H. W. Herrera. 2017. CDF checklist of Galapagos ants, bees, wasps and related groupsFCD lista de especies de hormigas, abejas, avispas y otros grupos relacionados de Galápagos. In: F. Bungartz, H. W. Herrera, P. Jaramillo, N. Tirado, G. Jiménez-Uzcátegui, D. Ruiz, A. Guézou \& F. Ziemmeck (Eds.). Charles Darwin Foundation Galapagos Species Checklist-Lista de Especies de Galápagos de la Fundación Charles Darwin. Charles Darwin Foundation / Fundación Charles Darwin, Puerto Ayora, Galapagos. Available from http://darwinfoundation.org/datazone/ checklists/terrestrial-invertebrates/hymenoptera/ (accessed 15 November 2017).

Kleindorfer, S. \& R. Y. Dudaniec. 2016. Host-parasite ecology, behavior and genetics: a review of the introduced fly parasite Philornisdownsi and its Darwin's finch hosts. BMC Zoology 1-19. DOI 10.1186/s40850-016-0003-9.

Linsley, E. G. \& R. L. Usinger. 1966. Insects of the Galápagos Islands. Proceedings of the California Academy of Sciences 33(7):113-196.

Lovejoy, N. R., S. P. Mullen, G. A. Sword, R. F. Chapman \& R. G. Harrison. 2006. Ancient TransAtlantic Flight Explains Locust Biogeography: Molecular Phylogenetics of Schistocerca. Proceedings of the Royal Society, Series B, Biological Sciences 273(1588):767-774.

Lucañas, C. C. \& M. Olmi. 2017. First record of the genus Caenosclerogibba Yasumatsu, 1958 (Hymenoptera: Sclerogibbidae) from the Philippines. Checklist 13(2):1-4.

Lubin, Y. D. 1984. Changes in the native fauna of Galapagos Islands following invasion by the little red fire ant Wasmannia auropunctata. Biological Journal of the Linnean Society 21:229-242.

Olmi, M. 2005. A revision of the world Sclerogibbidae (Hymenoptera, Chrysidoidea) Frustula Entomologica (N.S.) 26-27(39-40):46-193.

Olmi, M. 2006. Familia Sclerogibbidae, pp. 393-396. In: F. Fernández \& M. J. Sharkey (Eds.). Introducción a los Hymenoptera de la Región Neotropical. Sociedad Colombiana de Entomología \& Universidad Nacional de Colombia, Bogotá, 894 pp.

Parent, C. E., A. Caccone \& K. Petren. 2008. Colonization and diversification of Galápagos terrestrial fauna: a phylogenetic and biogeographical synthesis. Philosophical Transactions of the Royal Society: Biological Sciences 363(1508):3347-3361.

Peck, S. B. 1996. Diversity and distribution of the orthopteroid insects of the Galápagos Islands, Ecuador. Canadian Journal of Zoology 74(8):1497-1510.

Peck, S. B. 2001. Smaller Orders of Insects of the Galápagos Islands, Ecuador: Evolution, Ecology and Diversity. NRC Research Press, Ottawa, 278 pp.

Peck, S. B. 2006. The Beetles of the Galapagos Islands, Ecuador: Evolution, Ecology, and Diversity (Insecta: Coleoptera). NRC Research Press, Ottawa, 313 pp.

Roque-Albelo, L. \& B. Landry. 2016. CDF checklist of Galapagos butterflies and moths - FCD lista de especies de mariposas y polillas de Galápagos. In: F. Bungartz, H. W. Herrera, P. Jaramillo, 
N. Tirado, G. Jiménez-Uzcátegui, D. Ruiz, A. Guézou \& F. Ziemmeck (Eds.). Charles Darwin Foundation Galapagos Species Checklist-Lista de Especies de Galápagos de la Fundación Charles Darwin. Charles Darwin Foundation / Fundación Charles Darwin, Puerto Ayora, Galápagos. Available from http://darwinfoundation.org/datazone/checklists/terrestrial-invertebrates/ lepidoptera/ (accessed 15 November 2017)

Schluter, D. 1986. Character Displacement between distantly related taxa? Finches and bees in the Galapagos. The American Naturalist 127(1):95-102.

Steadman, D. W. 2009. La diversidad de vertebrados: una mirada a través del tiempo, pp. 46-52. In: T. De Roy (Ed.). Galápagos, Cincuenta Años de Ciencia y Conservación. Parque Nacional Galápagos, Imprenta Aguilera, Quito, 237 pp.

Sulloway, F. J. 1982. Darwin and his finches: the evolution of a legend. Journal of the History of Biology 15(1):1-53.

Szumik, C. A. 2012. Embioptera. pp. 263-269. In: J. Rafael, et al. (Eds.). Insetos do Brasil: Diversidade e Taxonomia. Holos Editora, Riberao Preto, 795 pp.

Tullis, P. 2006. Galápagos stampede. Scientific American 314(4):52-57.

Williams, D. F. \& P. M. Whelan. 1991. Polygynous colonies of Solenopsis geminata (Hymenoptera: Formicidae) in the Galapagos Islands. The Florida Entomologist 74:368-371.

Received 11 Sep 2017; accepted 15 Jan 2018 by D. J. Bennett. Publication date 30 Mar 2018 